\title{
New and little known species of Falsolucidota Pic, 1921 from New Guinea (Coleoptera: Lycidae)
}

\author{
Новые и малоизвестные виды Falsolucidota Pic, 1921 \\ из Новой Гвинеи (Coleoptera: Lycidae)
}

\author{
Sergey V. Kazantsev \\ С.В. Казанцев
}

Insect Centre, Donetskaya 13-326, Moscow 109651, Russia.

Инсект-центр, ул. Донецкая 13-326, Москва 109651, Россия. E-mail: kazantss@mail.ru

KEY WORDS: Coleoptera, Lycidae, new species, Papuan regions.

КЛЮЧЕВЫЕ СЛОВА: Coleoptera, Lycidae, новые виды, Папуасская область.

ABSTRACT: Five new species of net-winged beetles from a metriorrhynchine genus Falsolucidota Pic, 1921: F. curticollis, $F$. paula, $F$. planipennis, F rajampatensis and $F$. telnovi spp.n. are described from New Guinea and adjacent islands. Autapomorphies of Falsolucidota are discussed. Falsolucidota testaceicollis Pic, 1921, the type species of Falsolucidota, and Marena tristis Kazantsev, 2007, the type species of Marena Kazantsev, 2007, are illustrated.

РЕЗЮМЕ: Из Новой Гвинеи описывается пять новых видов жуков-краснокрылов родов Falsolucidota Pic, 1921: F. curticollis, F. paula, F. planipennis, $F$. rajampatensis и $F$. telnovi spp.n. Обсуждаются аутопоморфии рода Falsolucidota. Приводятся иллюстрации Falsolucidota testaceicollis Pic, 1921, типового вида рода Falsolucidota, и Marena tristis Kazantsev, 2007, типового вида рода Marena Kazantsev, 2007.

\section{Introduction}

The genus Falsolucidota Pic, 1921, a member of the tribe Metriorrhynchini, is only known from the Papuan region. Ten species of this genus have so far been described [Pic, 1921; Kleine, 1926, 1933; Bocák, Bocáková, 1990; Bocák, 2002; Kazantsev, 2010a].

An opportunity to study the ample Lycidae collections of the Institut Royal de Sciences naturelles de Belgique, Bruxelles, the Erfurt Naturkundemuseum and the Entomological Society of Latvia enables me to make a further contribution to the knowledge of this genus. Examination of this material has already led to publication of several papers on metriorrhynchines [Kazantsev, 2007, 2010b, 2015a,b, 2016a,b]. Five new to science Falsolucidota species are described in the present paper, with Falsolucidota testaceicollis Pic, 1921, the type species of the genus Falsolucidota, and Marena tristis Kazantsev, 2007, the type species of the genus Marena Kazantsev, 2007, illustrated.

\section{Material and Methods}

Collecting methods yielding the examined netwinged beetles were light traps and canopy fogging (used by Dr. O. Missa from the Institut Royal de Sciences naturelles de Belgique) and beating from tree branches and hand collecting from low-strata vegetation (used by Dr. D. Telnov and other members of the Entomological Society of Latvia Expedition to New Guinea).

The studied specimens were glued on cardboard or transparent plastic mounting plates. For detailed examination they were relaxed in water; then the detached ultimate abdominal segments were treated for several hours in $10 \% \mathrm{KOH}$ at room temperature, and, with the extracted genitalia, placed in microvials with glycerin. MSP-1 zoom stereoscopic dissecting microscope with x880 magnification range was used. Photographs were taken with Canon EOS 6D camera and Canon MP-E 65 mm lens.

The following acronyms are used in the paper: ICM - Insect Center, Moscow; IRSN — Institut Royal de Sciences naturelles de Belgique, Bruxelles; MNHN Museum national d'Histoire naturelle, Paris; NME Naturkundemuseum, Erfurt.

\section{Taxonomy}

Falsolucidota Pic, 1921

Falsolucidota Pic, 1921: 9 type species: Falsolucidota testaceicollis Pic, 1921.

= Hemiconderis Kleine, 1926: 162 type species: Hemiconderis explicatus Kleine, 1926: 162 .

DISTRIBUTION. New Guinea and adjacent islands.

Falsolucidota testaceicollis Pic, 1921

Fig. 1.

Falsolucidota testaceicollis Pic, 1921: 9.

MATERIAL: Lectotype, o", "Roon" (printed label), "Falsolucidota n.g. testaceicollis n.sp." (Pic's manuscript label) (MNHN).

REMARKS. The description of Falsolucidota testaceicollis Pic, 1921 is very brief and the taxon is not illustrated [Pic, 1921]. Although an illustration of the aedeagus of the lectotype 
has already been published [Kazantsev, 2010a], a habitus photo of the lectotype is provided to add to the clarity of the taxon (Fig. 1). It differs from Falsolucidota explicata (Kleine, 1926) by the shorter antennae, which do not reach the elytral apices, and double rows of cells in all elytral interstices (in F. explicata interstices 3 and 4, except at humeri, bear single rows of cells), although the third primary elytral costa is similarly prominent only in the humeral area. Additionally, the penultimate ventrite in $F$. testaceicollis is medially without median dent, and the penultimate tergite is fused, not divided into two sclerites (as in Figs 14-15), whereas in F. explicata the penultimate ventrite is medially dentate, and the penultimate tergite is divided into two sclerites (Figs 2-3). The aedeagus in F. testaceicollis has two one-level spine-bearing rings in a scissors-like structure (similar to Fig. 16), while in F. explicata the spinebearing rings are located at different levels (Fig. 4).

DISTRIBUTION. Known only from the island of Roon, just off the northern coast of New Guinea.

\section{Falsolucidota paula Kazantsev, sp.n.} Figs 5-9

MATERIAL: Holotype, $\sigma^{7}$, Papua New Guinea, $38 \mathrm{~km} \mathrm{~N}$ Madang, 2 km NW Matukar, 6.III.1989, M. Holyńska leg. (ICM)

DESCRIPTION. Male. Uniformly dark brown to black.

Vertex with conspicuous longitudinal impression behind antennal prominence. Eyes moderately large, interocular distance ca. 1.1 times greater than eye diameter. Labrum small, transverse. Palps slender; ultimate palpomeres relatively small, subquadrate, flattened and glabrous at apex. Antennal sockets separated by narrow lamina. Antennae almost attaining to elytral apices, from antennomere 3 flattened; antennomere 2 short, transverse, antennomere $3 \mathrm{ca} .1 .2$ times longer than antennomere 4 ; antennomeres 3-11 with short semi-erect pubescence (Fig. 5).

Pronotum transverse, ca. 1.7 times as wide as long, with almost straight sides, bisinuate basally, with long acute posterior and conspicuous blunt anterior angles, anteriorly considerably produced forward; median cell diamond-shaped,

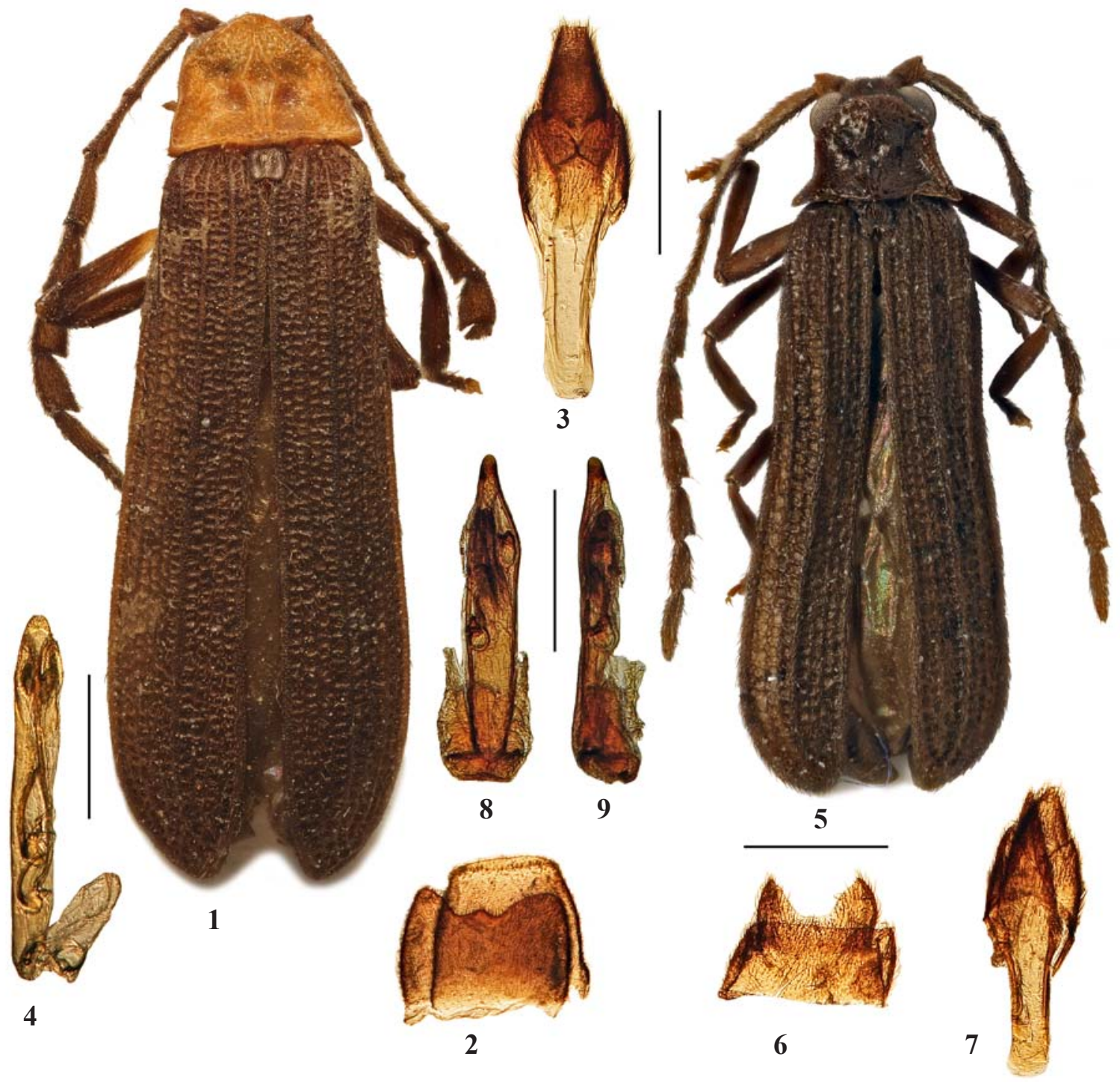

Figs 1-9. General view and details of Falsolucidota, males: $1-F$. testaceicollis; $2-4-F$. explicata; $5-9-F$. paula sp.n.; 1, $5-$ general view; 2, 6- penultimate ventrite; 3, 7 - ultimate abdominal segments; 4, 8-9 - aedeagus; 1 - lectotype; 5-9 - holotype; 1, 3, 4-5, 7 - dorsally; 2, 6 - ventrally; 9 - laterally. Scales: $0.5 \mathrm{~mm}$.

Рис. 1-9. Общий вид и детали строения Falsolucidota, самцы: $1-F$. testaceicollis; 2-4-F. explicata; 5-9 - F. paula sp.n.; 1, 5 - общий вид; 2, 6 - предпоследний вентрит; 3, 7 — вершинные сегменты брюшка; 4, 8-9 - эдеагус; 1 — лектотип; 5-9 — голотип; 1, 3, 4-5, 7 - сверху; 2, 6 - снизу; 9 - сбоку. Масштабные линейки: 0.5 мм. 
moderately broad, slightly rounded in the middle, reaching both anterior and posterior margins; lateral carinae almost obsolete, anterior cells absent; anterior fifth coarsely and sparsely punctate. Scutellum subquadrate, slightly narrowing distally, with small semi-circular notch at apex (Fig. 5).

Elytra long, 3.3 times longer than wide at humeri, flattened, slightly widened distally, with strong primary costa 2 and weakened, except at base, primary costa 3 ; interstices with double rows of irregular subquadrate cells, except interstices between primary costae 2 and 3 with single row of cells in the middle; bottom of cells velvety; pubescence mostly along costae, short and decumbent (Fig. 5). Tibiae and femurs straight, relatively narrow; tarsi short, ca. 0.5 length of tibiae, narrow.

Penultimate ventrite medially without dent; penultimate tergite fused, not divided into two sclerites (Figs 6-7). Aedeagus with straight, almost parallel-sided and conspicuously narrowed distally median lobe; inner sac with two twolevel ring-like structures bearing two spines (Figs 8-9).

Female. Unknown.

Length: $4.2 \mathrm{~mm}$. Width (humerally): $1.0 \mathrm{~mm}$.

ETYMOLOGY. The name of the new species is derived from the Latin for "small", alluding to its size.

DIAGNOSIS. Falsolucidota paula sp.n. can be readily separated from the somewhat similar $F$. niger (Bocák et Bocáková, 1990) by the smaller size, uniformly black body, as well as by the shape of the aedeagus, with straight, abruptly narrowed distally median lobe (Figs 5-9).

DISTRIBUTION. Known only from Madang, Papua New Guinea.

\section{Falsolucidota telnovi Kazantsev, sp.n.} Figs 10-11.

MATERIAL: Holotype, $\sigma^{7}$, E Indonesia, Raja Ampat, S Misool, $7.5 \mathrm{~km}$ W Biga, Biga R. valley, $02^{\circ} 01^{\prime} 23^{\prime \prime} \mathrm{S}, 130^{\circ} 12^{\prime} 38^{\prime \prime} \mathrm{E}, 45-78 \mathrm{~m}$, primeval lowland forest on limestone, river valley, 3.II.2012, D. Telnov leg. (NME); Paratype, $\sigma^{\top}$, same label (ICM).

DESCRIPTION. Male. Uniformly dark brown to black.

Vertex with inconspicuous round impression, bearing two small round bulges, behind antennal prominence. Eyes moderately large, interocular distance subequal to eye diameter. Labrum small, transverse. Palps slender; ultimate palpomeres relatively small, moderately elongate, parallel-sided, flattened at apex. Antennal sockets separated by narrow lamina. Antennae almost attaining to elytral apices, from antennomere 3 flattened; antennomere 2 short, transverse, antennomere $3 \mathrm{ca}$. 1.2 times longer than antennomere 4 ; antennomeres 3-11 with short decumbent pubescence (Fig. 10).

Pronotum transverse, ca. 1.7 times as wide as long, trapezoidal, bisinuate basally, with acute posterior and inconspicuous blunt anterior angles, semi-circular anteriorly; median oval, narrow, reaching both anterior and posterior margins; lateral carinae and anterior cells absent; anterior fifth coarsely and sparsely punctate. Scutellum transverse, narrowing distally, slightly emarginate at apex (Fig. 10).

Elytra long, 3.2 times longer than wide at humeri, flattened, slightly widened distally, with four equally developed primary costae; interstices with double rows of irregular subquadrate cells, except interstice 3 (between primary costae 2 and 3 ) with single row of cells in the middle; bottom of cells velvety; pubescence mostly along costae, short and decumbent (Fig. 10). Tibiae and femurs straight, relatively narrow; tarsi short, ca. 0.5 length of tibiae, tarsomeres narrow.

Aedeagus with straight, gradually tapering distally and rounded at apex median lobe; inner sac with two comma-like structures; phallobasal membrane short (Fig. 11).

Female. Unknown.
Length: 4.8-4.9 mm. Width (humerally): $1.1-1.2 \mathrm{~mm}$.

ETYMOLOGY. The new species is named after Dr. D. Telnov, collector of the type series.

DIAGNOSIS. Falsolucidota paula sp.n. can be readily separated from the similarly coloured $F$. paula sp.n. by the short posterior pronotal angles, weaker elytral reticulation, as well as by the shape of the aedeagus, with rounded distally median lobe with two comma-like inner sac structures (Figs 10-11).

DISTRIBUTION. Known only from Misool.

\section{Falsolucidota curticollis Kazantsev, sp.n.}

$$
\text { Fig. } 12 .
$$

MATERIAL: Holotype, + , Indonesia, Irian Jaya, Nabire area, road Nabire-Ilaga, $3^{\circ} 29.517^{\prime} \mathrm{S}, 135^{\circ} 43.913^{\prime} \mathrm{E}, 750$ m, LEK, X.1997, M. Balke leg. (NME).

DESCRIPTION. Female. Dark brown to black; ultimate palpomeres, ventrum, pronotum, scutellum, elytra proximally along suture, abdomen basally, coxae, trochanters, basal halves of femoris and bases of tibiae orange testaceous.

Vertex with inconspicuous transverse impression behind antennal prominence. Eyes relatively small, interocular distance ca. 1.7 times greater than eye diameter. Labrum small, short, transverse. Palps small; maxillary palps widened distally; penultimate maxillary palpomere about as long as wide; ultimate maxillary palpomere transverse, slightly flattened at apex. Antennal sockets separated by minute lamina. Antennae almost exceeding elytral apices by two ultimate antennomeres, antennomeres from antennomere 3 flattened, elongate, almost parallel-sided; antennomere 2 short, transverse, antennomere 3 subequal in length to antennomere 4 ; antennomeres 3-11 with short semi-erect pubescence (Fig. 12).

Pronotum transverse, ca. 1.5 times as wide as long, with slightly concave sides, bisinuate basally, with long acute posterior and conspicuous blunt anterior angles, anteriorly moderately semi-circularly produced forward; median cell diamond-shaped, broad, reaching posterior and connected to margin by short costa; lateral carinae pronounced, almost straight, anterior cells absent; anterior fifth coarsely and sparsely punctate. Scutellum transverse, parallel-sided, with triangular incision at apex (Fig. 12).

Elytra narrow, long, ca. 4 times longer than wide at humeri, concave in the middle, diverging posteriorly, with primary costa 1 weakened in distal half and primary costa 3 weakened in distal four fifths; interstices with double rows of irregular subquadrate cells, except interstices 1 and 2 with single row of cells in distal third and interstices 3 and 4 with single row of cells in distal three fourths; pubescence scarce and short (Fig. 12). Tibiae and femurs straight, narrow; tarsi short, ca. 0.5 length of tibiae, narrow; tarsomere 1 without plantar pad, tarsomeres 2-4 with apical plantar pad.

Male. Unknown.

Length: $7.2 \mathrm{~mm}$. Width (humerally): $1.4 \mathrm{~mm}$.

ETYMOLOGY. The name of the new species is derived from the Latin for "with short neck", alluding to the relative size of its pronotum.

DIAGNOSIS. Falsolucidota curticollis sp.n., belonging in the explicatus-group, can be readily separated from all its members by the short and transverse pronotum and narrow and concave in the middle elytra (Fig. 12).

DISTRIBUTION. Known only from the Nabire area, Irian Jaya.

\section{Falsolucidota planipennis Kazantsev, sp.n.} Figs 13-17.

MATERIAL: Holotype, O', E Indonesia, Raja Ampat Prov., Waigeo Island, $10-13 \mathrm{~km} \mathrm{NE}$ Waisai, $00^{\circ} 21^{\prime} 17^{\prime} \mathrm{S}, 130^{\circ} 54^{\prime} 37^{\prime \prime} \mathrm{E}, \sim$ 


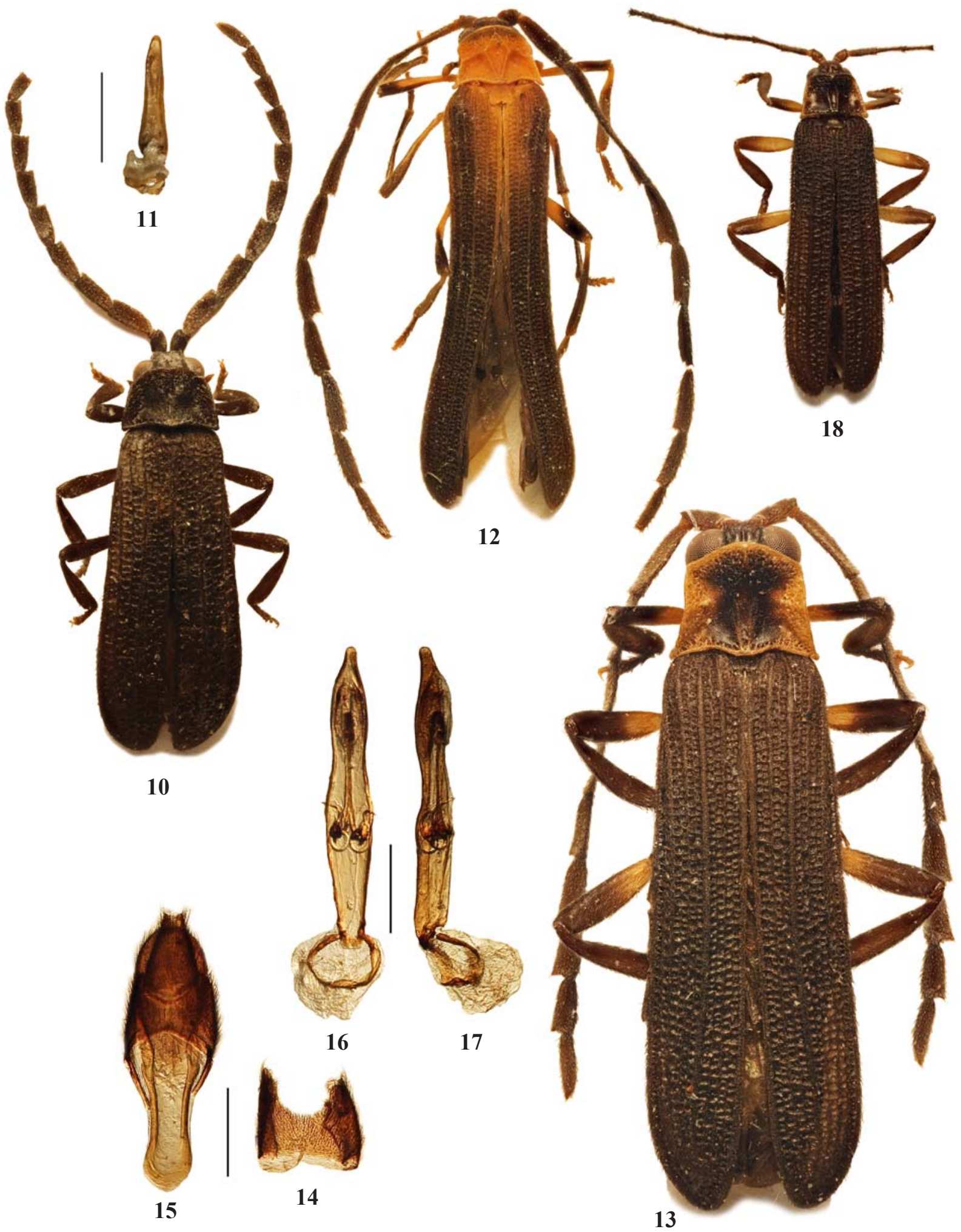

Figs 10-18. General view and details of Falsolucidota, holotypes: 10-11 - F. telnovi sp.n.; $12-$ F. curticollis sp.n.; $13-17-F$. planipennis sp.n.; 18 - F. rajampatensis sp.n.; 10, 12-13, 18 - general view; 11, 16-17 - aedeagus; 14 - penultimate ventrite; 15 - ultimate abdominal segments; $10-11,13-17$ - male; 12,18 - female; $10,12-14,16,18$ - dorsally; 11,15 - ventrally; 17 — laterally. Scales: $0.5 \mathrm{~mm}$.

Рис. 10-18. Общий вид и детали строения Falsolucidota, голотипы: 10-11 - F. telnovi sp.n.; $12-$ F. curticollis sp.n.; 13-17 -F. planipennis sp.n.; 18 - F. rajampatensis sp.n.; 10, 12-13, 18 - общий вид; 11, 16-17 — эдеагус; 14 - предпоследний вентрит; 15 вершинные сегменты брюшка; 10-11, 13-17 - самец; 12, 18 - самка; 10, 12-14, 16, 18 - сверху; 11, 15 - снизу; 17 - сбоку. Масштабные линейки: 0.5 мм. 
$70 \mathrm{~m}$, primeval lowland rainforest, on limestone, 16.II.2012, D. Telnov leg. (NME); paratype, O', same label (ICM).

DESCRIPTION. Male. Dark brown; pronotal margins, wider at sides, more narrow anterior and posteriorly, and basal halves of femoris testaceous.

Vertex with conspicuous trident impression behind antennal prominence. Eyes large, interocular distance ca. 1.4 times shorter than eye diameter. Labrum small, transverse, short, slightly emarginate anteriorly. Palps slender; ultimate palpomeres elongate, slightly narrowed and flattened at apex. Antennal sockets separated by minute lamina. Antennae almost attaining to elytral apices, from antennomere 3 flattened; antennomere 2 short, transverse, antennomere $3 \mathrm{ca}$. 1.15 times longer than antennomere 4; antennomeres 3-11 with short decumbent pubescence (Fig. 13).

Pronotum transverse, ca. 1.3 times as wide as long, with almost straight sides, bisinuate basally, with long acute posterior and conspicuous blunt anterior angles, anteriorly triangularly produced forward; median cell diamond-shaped, moderately broad, slightly rounded in the middle, reaching posterior and connected to margin by short costa; lateral carinae greatly reduced, anterior cells absent; anterior fifth coarsely and sparsely punctate. Scutellum transverse, trapezoidal, slightly narrowing distally, slightly triangularly emarginate at apex (Fig. 13).

Elytra long, ca. 3.5 times longer than wide at humeri, relatively broad, flattened, parallel-sided, with strong primary costa 2 and weakened, except at proximal fourth, primary costae 1 and 3; all interstices with double rows of irregular subquadrate cells; pubescence short and scarce (Fig. 13). Tibiae and femurs straight, relatively narrow; tarsi short, ca. 0.5 length of tibiae, narrow; tarsomere 1 without plantar pad, tarsomeres 2-4 with apical plantar pad.

Penultimate ventrite medially incised, without median dent. Penultimate tergite fused, not divided into two sclerites. Aedeagus with straight, both in ventral and in lateral view, abruptly narrowed distally median lobe; inner sac with two one-level ring-like structures and two outwardly bent spines (Figs 14-17).

Female. Unknown.

Length: 6.4-7.6 mm. Width (humerally): 1.5-1.8 $\mathrm{mm}$.

ETYMOLOGY. The name of the new species is derived from the Latin for "with even and/or flat body", alluding to its relatively flat elytra with even reticulation.

DIAGNOSIS. Falsolucidota planipennis sp.n. appears to be close to $F$. testaceicollis, separable by the infuscated pronotal disk and by the shape of the aedeagus, with more abruptly narrowed distally and straighter in lateral view median lobe (Figs 13-17).

DISTRIBUTION. Known only from Waigeo Island, Raja Ampat Province, in East Indonesia.

\section{Falsolucidota rajampatensis Kazantsev, sp.n.} Fig. 18.

MATERIAL: Holotype, 9 , E Indonesia, Raja Ampat Prov., SW Misool, distr. Misool Utara, $2.5 \mathrm{~km}$ NNW Aduvey (Adua) village, Hakau River valley, $01^{\circ} 58^{\prime} 46^{\prime \prime} \mathrm{S}, 129^{\circ} 4^{\prime} 37^{\prime \prime} \mathrm{E}$, primeval lowland forest, river valley, beaten from branches, 29.III.2009, D. Telnov \& K. Greke leg. (NME).

DESCRIPTION. Female. Dark brown; antennomere 2, narrow pronotal sides and basal two thirds of femoris testaceous.

Vertex with two small, but deep round impressions behind antennal prominence. Eyes small, interocular distance ca. 1.4 times greater than eye diameter. Labrum small, transverse. Palps slender; ultimate palpomeres relatively small, elongate, narrowed and glabrous at apex. Antennal sockets separated by minute lamina. Antennae almost attaining to elytral apices, from antennomere 3 flattened; antennomere 2 short, transverse, an- tennomere 3 subequal in length to antennomere 4; antennomeres 3-11 with short semi-erect pubescence (Fig. 18).

Pronotum transverse, ca. 1.6 times as wide as long, trapezoidal, almost straight basally and anteriorly, with acute posterior and rounded blunt anterior angles; median cell oval, moderately broad, slightly reaching both anterior and posterior margins; lateral carinae obsolete, anterior cells absent; anterior fifth coarsely and sparsely punctate. Scutellum transverse, slightly narrowing distally, slightly broadly emarginate at apex (Fig. 18).

Elytra long, 3.6 times longer than wide at humeri, flattened, parallel-sided, with stronger primary costa 2 and weakened, except at base, primary costa 3 ; interstices with double rows of irregular subquadrate cells, except interstice 2 , with single row of cells in the middle, and interstices 3 and 4, with single row of cells in distal twi thirds; pubescence mostly along costae, short and erect (Fig. 18). Tibiae and femurs straight, relatively narrow; tarsi short, ca. 0.55 length of tibiae, tarsomeres relatively narrow.

Male. Unknown.

Length: $5.2 \mathrm{~mm}$. Width (humerally): $1.2 \mathrm{~mm}$.

ETYMOLOGY. The name of the new species is derived from the province Raja Ampat, where the unique specimen was collected.

DIAGNOSIS. Falsolucidota rajampatensis sp.n. can be readily separated from the similarly coloured congeners by the weak irregular elytral reticulation (Fig. 18).

DISTRIBUTION. Known only from Misool Island, Raja Ampat Province, in East Indonesia.

Marena Kazantsev, 2007

Marena Kazantsev, 2007: 297 type species: Marena tristis Kazantsev, 2007

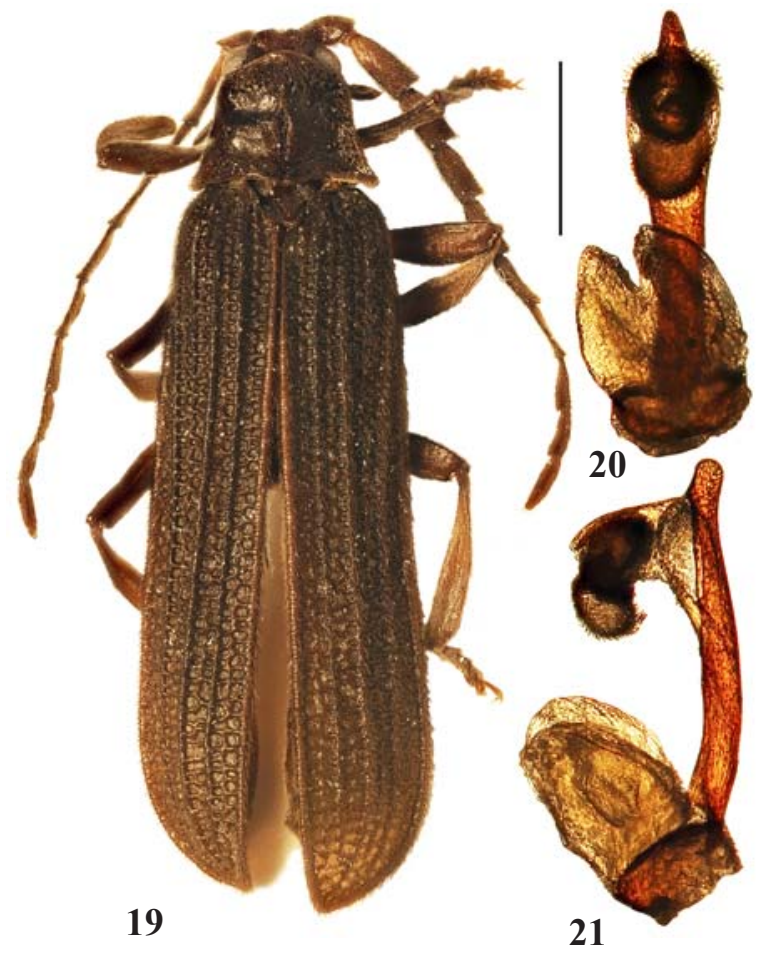

Figs 18-21. General view and details of Marena tristis, paratype male: 19 - general view; 20-21 - aedeagus; 19 - dorsally; $20-$ ventrally; 21 - laterally. Scale: $0.5 \mathrm{~mm}$.

Рис 18-21. Общий вид и детали строения Marena tristis, паратип самец: 19 - общий вид; 20-21 - эдеагус; 19 - сверху; 20 - снизу; 21 - сбоку. Масштабная линейка: 0.5 мм. 
REMARKS. Three species of this genus are known [Kazantsev, 2007]. Marena looks somewhat similar to Falsolucidota, having similarly shaped antennae and quite similar elytral and, partly, pronotal structure. However, the aedeagus of Marena is quite unlike that of Falsolucidota: it has no sclerotized inner sac structures, its inner sac actually located outside the median lobe of the aedeagus (Figs 2021). Besides, its median pronotal cell never attains the anterior margin (Fig. 19).

DISTRIBUTION. Madang, New Guinea.

\section{Marena tristis Kazantsev, 2007}

Figs 19-21.

Marena tristis Kazantsev, 2007: 299

MATERIAL: Holotype, $\sigma^{7}$, Papua New Guinea, Madang prov. Baiteta, fogging, 7.VII.1995, O. Missa leg. (IRCN); paratypes, 2 $\sigma^{7} \sigma^{7}$ : same label (ICM and IRCN).

DISTRIBUTION. Known only from Madang, New Guinea.

\section{Discussion}

The genus Falsolucidota has two principal morphological types, the testaceicollis type, characterized by complete double rows of cells in elytral interstices 3 and 4 , and the explicata type, with a single row of cells in elytral interstices 3 and 4, except at humeri. The two type species of the group, $F$. testaceicollis and F. explicata, also differ in the length of their antennae, in $F$. explicata the latter noticeably exceeding the elytra in length, while in $F$. testaceicollis not quite reaching the elytral apices, the pronotal structure, with lateral carinae fully developed in $F$. explicata and reduced in $F$. testaceicollis, the structure of the penultimate ventrite, which is medially dentate in $F$. explicata and medially incised in F. testaceicollis, the structure of the penultimate tergite, which is divided into two sclerites in $F$. explicata and fused in $F$. testaceicollis, and the aedeagus, with one-level spine-bearing ring-like structures in the median lobe in F. testaceicollis and twolevel similar structures in $F$. explicata, - which may seem to testify to the occurrence of two distinct genuslevel taxa within this group. Some species of the genus, i.e., F. planipennis sp.n. or F. curticollis sp.n., can be easily attributed to one of these types, e.g., the former to the testaceicollis type, the latter to the explicata type. However, some of their congeners, e.g., F. paula sp.n., occupy an intermediate position between the two groups, possessing elytral structure as in the explicata type and pronotal structure and antennal length as in the testaceicollis type. While its aedeagal structure corresponds to the explicata type, the structure of its penultimate tergite and ventrite is as in the testaceicollis type. This does not allow identifying reliable autapomorphies for the two lineages and regarding them as separate genus-level taxa, at least at the current level of knowledge of the group.

ACKNOWLEDGEMENTS. It is my pleasant duty to express gratitude to Dr. P. Grootaert (Institut Royal de Sciences naturelles de Belgique, Bruxelles), Dr. M. Hartmann (Naturkundemuseum Erfurt), Dr. A. Kopetz (Kerspleben), Dr. J. Menier (Museum national d'Histoire naturelle, Paris) and Dr. D. Telnov (Entomological Society of Latvia, Riga), through whose courtesy I was able to study the Lycidae collections under their care. My sincere thanks are also due to Dr. R. Holyński (Milanowek, Poland) for providing interesting additional material collected during his and Dr. M. Holyńska's entomological expeditions to New Guinea.

\section{References}

Bocák L. 2002. Generic revision and phylogenetic analysis of the Metriorrhynchinae (Coleoptera: Lycidae) // Europ. J. Entomol. Vol.99. P.315-351.

Bocák L., Bocáková M. 1990. Revision of the genus Hemiconderis (Coleoptera, Lycidae) // Acta Entomol. Bohemoslov. Vol.87. P.209-220.

Kazantsev S.V. 2007. Marena gen.n., new Metriorrhynchini genus from New Guinea (Coleoptera: Lycidae) // Russian Entomol. J. Vol.16. No.3. P.297-300.

Kazantsev S.V. 2010a. On the status and systematic position of the genera Falsolucidota Pic, 1921 and Macrolycinella Pic, 1922, with notes on Lopheros LeConte, 1881 (Lycidae, Coleoptera) // Russian Entomol. J. Vol.18 (for 2009). No.4. P.277-283.

Kazantsev S.V. 2010b. New taxa of Papuan net-winged beetles (Lycidae, Coleoptera) // Latvijas Entomologs. Vol. 48. P.92-100.

Kazantsev S.V. 2015a. New Xylobanus and related taxa of netwinged beetles from New Guinea (Coleoptera: Lycidae) // Russian Entomol. J. Vol.24. No.2. P.107-118.

Kazantsev S.V. 2015b. New species of Metriorrhynchus Gemminger et Harold, 1869 and Porrostoma Laporte, 1838 from New Guinea (Coleoptera: Lycidae) // Russian Entomol. J. Vol. 24. No.3. P.211-233

Kazantsev S.V. 2016a. New Procautires species from New Guinea (Coleoptera: Lycidae) // Russian Entomol. J. Vol.25. No.1. P.35-47.

Kazantsev S.V. 2016b. Review of Ditua Waterhouse, 1879 with description of six new species (Coleoptera: Lycidae) // Russian Entomol. J. Vol.25. No.2. P.1-10.

Kleine R. 1926. Coleoptera. Lycidae // Nova Guinea. Résultats des Expéditions scientifiques à la Nouvelle Guinée. Vol.15. P.91195.

Kleine R. 1933. Pars 123: Lycidae // Coleopterorum Catalogus auspiciis et auxilio W. Junk editus a Schenkling. Berlin: W. Junk. 145 pp.

Pic M. 1921-1922. Contributions à l'étude des Lycides // L'Echange, hors texte. Vol.37-38. Nos.404-410. P.1-28. 